\title{
Surgeon teachers and millennial learners: Bridging the generation gap
}

\author{
Jessica G. Y. Luc, MD, ${ }^{\mathrm{a}}$ Mara B. Antonoff, MD, ${ }^{\mathrm{b}}$ Ara A. Vaporciyan, MD, MHPE, ${ }^{\mathrm{b}}$ and \\ Bobby Yanagawa, $\mathrm{MD}, \mathrm{PhD}^{\mathrm{c}}$
}

In a recent informal survey of surgeons, when asked to describe their Millennial trainees, common responses range from "entitled," "lazy," and "unable to take criticism" to "socially conscious" and "tech savvy." The unfairness of such criticisms is reflected in the popular social media response: "Ok Boomer!" The Millennial generation is different than any of the past, but this is true, to a degree, of every generation. As surgical educators, mentors, and role models, it is incumbent on us to understand how membership in our own generation affects our teaching style. Importantly, we need to better understand the current generation of surgical learners, their strengths and weaknesses, to tailor our surgical education methods. Likewise, trainees must appreciate the surgical culture of our current surgeons and the real and perceived challenges of teaching how to operate in these changing times.

Our Millennial learners are undergoing cardiothoracic surgical training at a time when operative teaching faces challenges from multiple angles, including but not limited to (1) time pressure on surgeons for operative efficiency; (2) trainee work-hour restrictions ${ }^{1,2}$; (3) increasing scrutiny of public reporting of surgical outcomes ${ }^{1}$; (4) obstacles related to teaching less-experienced, direct-entry integrated 6-year trainees ${ }^{3}$; (5) surgical training in the setting of sicker patients requiring higher-risk surgical interventions; and (6) less opportunity to perform routine open cases with the rapid expansion of technically challenging minimally invasive robotic, endovascular, and video-assisted procedures. $^{2}$ There are even less opportunities for junior trainees to gain basic tissue handling and suture skills during surgical revascularization as endovascular vein harvest has become more common and with the shift toward multiple arterial grafting. ${ }^{4}$ Fewer top trainees are entering our specialty. ${ }^{5}$ To continue to attract the best and the

\footnotetext{
From the a Division of Cardiovascular Surgery, Department of Surgery, University of British Columbia, Vancouver, British Columbia, Canada; ${ }^{b}$ Department of Thoracic and Cardiovascular Surgery, University of Texas MD Anderson Cancer Center, Houston, Tex; and 'Division of Cardiac Surgery, St Michael's Hospital, University of Toronto, Toronto, Ontario, Canada.

Received for publication June 24, 2019; revisions received March 8, 2020; accepted for publication March 22, 2020; available ahead of print June 23, 2020.

Address for reprints: Bobby Yanagawa, MD, PhD, Division of Cardiac Surgery, University of Toronto, St Michael's Hospital, 30 Bond St, 8th Floor, Bond Wing

Toronto, Ontario M5B 1W8, Canada (E-mail: yanagawab@smh.ca).

J Thorac Cardiovasc Surg 2021;162:334-41

$0022-5223 / \$ 36.00$

Copyright (c) 2020 by The American Association for Thoracic Surgery

https://doi.org/10.1016/j.jtcvs.2020.03.177
}

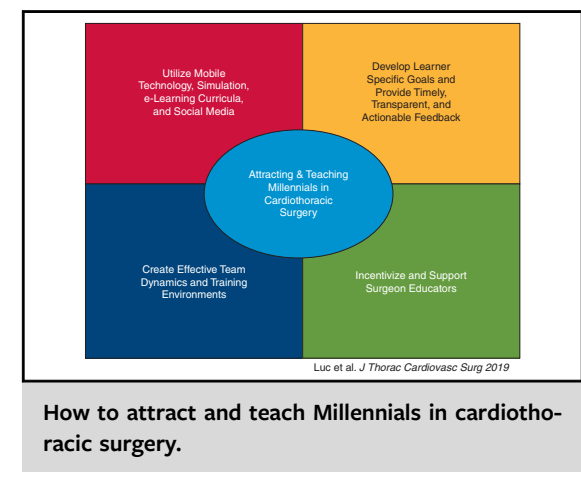

\begin{abstract}
CENTRAL MESSAGE
Awareness of generational differences in learning can help cardiothoracic surgeons of today become more effective mentors and educators for Millennial cardiothoracic surgeons of tomorrow.
\end{abstract}

See Commentaries on pages 342 and 343.

brightest, we must modernize the training experience to meet the needs of a newer generation of learners (Figure 1).

We look deeper into the concept of generations and the characteristics of each generation, and suggest strategies to tailor surgical education to the Millennial generation.

\section{WHAT IS A GENERATION?}

A generation is a category of people based on ranges of birth year. Those in a generation share and are shaped by common life events and experiences. ${ }^{6}$ The last 3 generations include Baby Boomers (born between 1946-1964), Generation X (born between 1965-1979), and Millennials (born between1980-1995). ${ }^{7,8}$

Generational diversity brings differences in values and expectations affecting perceptions and behavior. ${ }^{6}$ Generational context and the social construct in which training occurs affect learning styles, communication preferences, and expectations of how individuals interact with the world around them. We do not want to paint an 


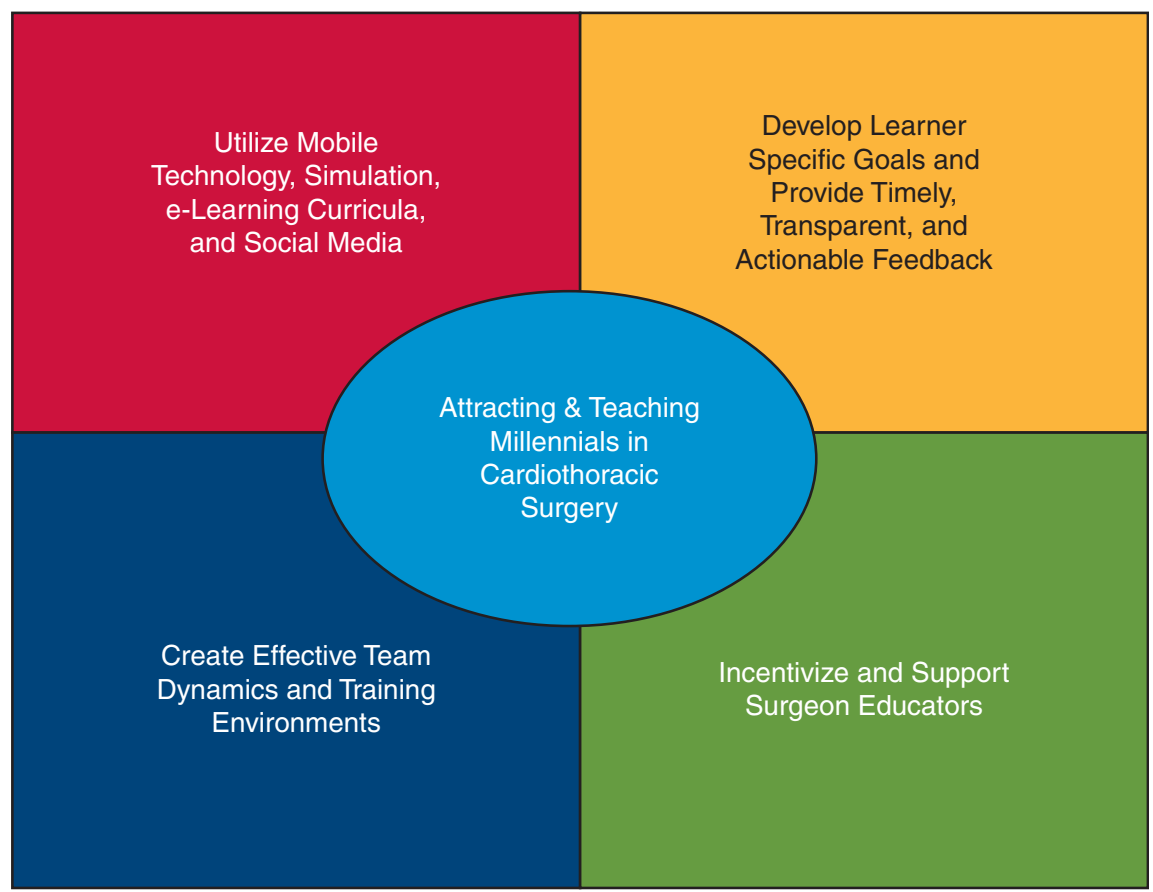

Luc et al. J Thorac Cardiovasc Surg 2019

FIGURE 1. Ways to attract and teach Millennials in cardiothoracic surgery.

entire generation of unique individuals with the same brush. However, there are some overarching generational traits that, if better understood, may help bridge the proverbial generational gap between teachers and learners with the overall goal to become more effective mentors and educators.

\section{THE GENERATIONS}

\section{The Baby Boomers}

Currently between the ages of 55 to 73 years, Baby Boomers primarily comprise the cardiothoracic surgical senior faculty. ${ }^{7,8}$ In the Western world, Baby Boomers lived through the post-World War II economy, Cold War, Vietnam War, and Civil Rights Movement (Tables 1-3). Baby Boomers have been described as "workaholics" who are idealistic, driven, and ambivalent toward authority, and value leaders with credibility, are farsighted in their vision, and desire respect for their contributions. ${ }^{7,8}$ Their metrics for job performance are hours worked and financial rewards. Their identities tend to be closely linked to their careers. ${ }^{7,8}$

\section{Generation X}

Currently between the ages of 40 and 54 years, Generation $\mathrm{X}$ are early to mid-career cardiothoracic surgical faculty. ${ }^{7,8}$ In the Western world, they lived through the Gulf War, the fall of the Berlin Wall, the Women's Rights Movement, the acquired immunodeficiency syndrome epidemic, and the introduction of the personal computer, and often are the first generation in which both parents worked outside the home (Tables 1-3). Generation Xers have been described as individualistic; they value work-life balance and set their own limits. ${ }^{7,8}$ They believe in being evaluated by their accomplishments rather than quantity of time spent at work and are often direct and outspoken.,

\section{Millennials}

Our youngest colleagues aged 24 to 39 years, Millennials comprise some early junior faculty and most all cardiothoracic surgical trainees. ${ }^{7,8}$ Millennials live in the digital age and have never known a time without the Internet. They are globally oriented and accept multiculturalism and diversity as a way of life. ${ }^{7,8}$ In the Western world, they lived through the geopolitical impact of September 11, 2001, global terrorism, wars in Iraq and Afghanistan, and weakening of the global economy (Table 1). They have been described as self-confident, optimistic, collaborative, and technologically savvy. Born during an era of massive technology growth, Millennials are accustomed to mobile Internet connection and social media. ${ }^{7,8}$ They believe in a continuum of work-life and personal-life but not a work-life balance per se. ${ }^{7,8}$

\section{WHAT IS THE LEARNING STYLE OF THE MILLENNIAL?}

\section{Use of Technology}

As mentioned, Millennials live in a postdigital world. They are technologically adept and often prefer online 
TABLE 1. Generational history and key life events

\begin{tabular}{|c|c|c|c|c|}
\hline & \multicolumn{4}{|c|}{ Generations } \\
\hline & Baby Boomer & Generation X & Millennials & Generation Z \\
\hline Years ${ }^{9-11}$ & 1946-1964 & $1965-1979$ & $1980-1995$ & $1996-2010$ \\
\hline Size (approximately) ${ }^{7}$ & 80 million & 50 million & 70 million & 70 million \\
\hline Heros $^{7}$ & Themselves & Anti-heroes & Parents & Themselves \\
\hline Significant life events ${ }^{7}$ & $\begin{array}{l}\text { Vietnam War } \\
\text { Cold War } \\
\text { Post-Great Depression } \\
\text { Post-World War II } \\
\text { Civil Rights Act } \\
\text { Rock and Roll }\end{array}$ & $\begin{array}{l}\text { Women's rights } \\
\text { Gulf War } \\
\text { Fall of the Berlin Wall } \\
\text { Challenger space shuttle } \\
\text { Computers } \\
\text { AIDS }\end{array}$ & $\begin{array}{l}9 / 11 \\
\text { War in Iraq } \\
\text { Columbine shooting } \\
\text { Internet } \\
\text { Diversity }\end{array}$ & $\begin{array}{l}\text { The Great Recession } \\
\text { The first black president } \\
\text { ISIS }\end{array}$ \\
\hline Technology $^{7}$ & $\begin{array}{l}\text { Color television } \\
\text { Typewriters } \\
\text { Landline telephones } \\
\text { Large computers }\end{array}$ & $\begin{array}{l}\text { Cell phones } \\
\text { Cable television } \\
\text { Video games }\end{array}$ & $\begin{array}{l}1000 \text { TV channels } \\
\text { Internet } \\
\text { Smartphones } \\
\text { iPods } \\
\text { Instant networking }\end{array}$ & $\begin{array}{l}\text { Artificial intelligence } \\
\text { Automatism } \\
\text { Internet } \\
\text { Smartphones } \\
\text { Wearable technology }\end{array}$ \\
\hline Qualities $^{7}$ & $\begin{array}{l}\text { Optimistic, idealistic, } \\
\text { educated, competitive, } \\
\text { diplomatic, loyal, } \\
\text { high expectations, } \\
\text { opinionated }\end{array}$ & $\begin{array}{l}\text { Cynical, resourceful, } \\
\text { independent, } \\
\text { entrepreneurial, } \\
\text { pragmatic, } \\
\text { straightforward }\end{array}$ & $\begin{array}{l}\text { Technologically savvy, } \\
\text { empowered, confident, } \\
\text { collaborative, } \\
\text { community-centered, } \\
\text { versatile, inclusive and } \\
\text { accepting }\end{array}$ & $\begin{array}{l}\text { Technologically savvy, } \\
\text { unique }\end{array}$ \\
\hline
\end{tabular}

AIDS, Acquired immune deficiency syndrome; ISIS, Islamic State of Iraq and the Levant.

versus in-person learning and communication. ${ }^{14}$ In cardiothoracic surgery, the success of the National Thoracic Surgery Online Curriculum, which includes expert-developed, text-based, case-based, and question and answer-based learning, ${ }^{15}$ e-Textbooks, ${ }^{15}$ apps, blogs, podcasts, free streaming videos, webinar, and simulations with gamification of learning, is an example of how technology has the potential to enhance surgical teaching. ${ }^{16}$

TABLE 2. Generational differences in learning strategies

\begin{tabular}{|c|c|c|c|c|}
\hline & \multicolumn{4}{|c|}{ Generations } \\
\hline & Baby Boomer & Generation X & Millennials & Generation Z \\
\hline $\begin{array}{l}\text { Way to learn } \\
\text { soft skills }{ }^{12}\end{array}$ & $\begin{array}{l}\text { On the job } \\
\text { Discussion groups } \\
\text { Assessment and } \\
\text { feedback }\end{array}$ & & & \\
\hline $\begin{array}{l}\text { Way to learn } \\
\text { hard skills }{ }^{12}\end{array}$ & Didactic & On the job & & On the job, simulation \\
\hline Feedback $^{7}$ & Only as needed & $\begin{array}{l}\text { Immediate and } \\
\text { continuous }\end{array}$ & & \\
\hline Learning style $^{13}$ & Facilitated & Independent & Collaborative and networked & Collaborative and networked \\
\hline Decision-making $^{13}$ & $\begin{array}{l}\text { Team informed } \\
\text { My decision }\end{array}$ & $\begin{array}{l}\text { Team included } \\
\text { Our decision }\end{array}$ & $\begin{array}{l}\text { Team decided } \\
\text { What all agreed to }\end{array}$ & $\begin{array}{l}\text { Team decided } \\
\text { What all agreed to }\end{array}$ \\
\hline Technology use $^{13}$ & Not adept & $\begin{array}{l}\text { Needed for maximum } \\
\text { engagement }\end{array}$ & Expected in all settings & Expected in all settings \\
\hline $\mathrm{Need}^{7}$ & Privacy, validation & $\begin{array}{l}\text { Flexibility, work-life } \\
\text { balance }\end{array}$ & $\begin{array}{l}\text { Instant gratification, feedback, } \\
\text { and sense of safety }\end{array}$ & $\begin{array}{l}\text { Instant gratification, feedback, } \\
\text { and sense of safety }\end{array}$ \\
\hline $\begin{array}{l}\text { Approach to } \\
\text { Authority }^{7}\end{array}$ & Ambivalent & Unimpressed & Tolerant & Tolerant \\
\hline
\end{tabular}


TABLE 3. Generational differences in approach to work and employment

\begin{tabular}{|c|c|c|c|c|}
\hline & \multicolumn{4}{|c|}{ Generations } \\
\hline & Baby Boomer & Generation X & Millennials & Generation $\mathbf{Z}$ \\
\hline Approach to work ${ }^{7}$ & $\begin{array}{l}\text { Live to work } \\
\text { Process-oriented }\end{array}$ & $\begin{array}{l}\text { Work to live } \\
\text { Results-driven }\end{array}$ & $\begin{array}{l}\text { Multitaskers } \\
\text { Results-driven }\end{array}$ & $\begin{array}{l}\text { Multitaskers, } \\
\text { connectedness }\end{array}$ \\
\hline Attitude to employer ${ }^{7}$ & $\begin{array}{r}\text { Value company } \\
\text { commitment }\end{array}$ & Loyal to people & Committed when dedica & , cause or product \\
\hline $\begin{array}{l}\text { Would stay with organization } \\
\text { for rest of working life }(\%)^{12}\end{array}$ & $65 \%$ & $40 \%$ & $20 \%$ & - \\
\hline $\begin{array}{l}\text { Reasons for staying in } \\
\text { an organization }\end{array}$ & $\begin{array}{l}\text { 1. Potential for advancement } \\
\text { 2. Learning and development } \\
\text { 3. Respect and recognition } \\
\text { 4. Quality of life } \\
\text { 5. Compensation }\end{array}$ & & & - \\
\hline Preferred leadership attributes ${ }^{8}$ & $\begin{array}{l}\text { 1. Credible } \\
\text { 2. Trusted } \\
\text { 3. Farsighted }\end{array}$ & & $\begin{array}{l}\text { 1. Listens well } \\
\text { 2. Dependable } \\
\text { 3. Dedicated }\end{array}$ & - \\
\hline $\begin{array}{l}\text { Areas in which they hope } \\
\text { to develop }\end{array}$ & $\begin{array}{l}\text { 1. Skills training } \\
\text { 2. Leadership } \\
\text { 3. Computer technology }\end{array}$ & $\begin{array}{l}\text { 1. Leadership } \\
\text { 2. Skills training } \\
\text { 3. Team building }\end{array}$ & $\begin{array}{l}\text { 1. Leadership } \\
\text { 2. Problem solving and } \\
\text { decision-making } \\
\text { 3. Skills training }\end{array}$ & - \\
\hline
\end{tabular}

Such online learning modules democratize learning for trainees/surgeons in remote or less-developed regions and can be updated and revised in real time with the emergence of new evidence or techniques. ${ }^{17}$ Evaluation of the impact of use of the National Thoracic Surgery Online Curriculum demonstrates that trainees who used the curriculum led to greater improvement in in-service training examination scores. $^{18}$

Social networking services such as Twitter have already digitized learning cases and social teaching files through hashtags ${ }^{19}$ as well as online TweetChat ${ }^{20}$ and live tweeting of our surgical society meetings ${ }^{21}$ with post hoc annotations and postpublication peer review. The Journal of Thoracic and Cardiovascular Surgery and Annals of Thoracic Surgery are using innovative ways to interact with and meet the educational needs of our trainees and surgeons through the creation of the Thoracic Surgery Social Media Network. ${ }^{20-25}$ The Thoracic Surgery Social Media Network engages Millennial learners, the surgical community and public through TweetChats, ${ }^{22}$ resulting in greater engagement of physicians, patients, and members of the public in the discussion of evidence-based cardiothoracic surgery literature, ${ }^{24,25}$ and improving nontraditional bibliometrics of dissemination of literature. ${ }^{23}$ These massive open online classrooms democratize information, facilitates crowd-sourcing of knowledge and peer review, and allow one to stay abreast of the ever-expanding body of knowledge in our profession both synchronously (with live lectures) or asynchronously (adjusted to the speed and timing of the learner who can repeat, fast-forward, or skip through content). ${ }^{20,21}$ The loudest voice may not always be the most accurate, and there is a risk of misinformation spread in the absence of some level of peer review. ${ }^{26}$ Another potential downside of online learning is the expansive volume of material, which can overwhelm the learner.

The benefits of using e-curricula to supplement cardiothoracic surgical training include (1) appeal to learners familiar with digital technology; (2) flexibility in time and location to comply with work-hour restrictions; (3) ability to accelerate video-recorded lectures with demonstrated similar effectiveness to traditional live attendance-students often watch videos in double time $^{27}$; and (4) standardized delivery of high-quality educational material and ability to track use and measure performance. ${ }^{15}$ For example, academic half-day lectures can be documented and stored, and simulation curriculum can be delivered and evaluated online (https://campus. meplis.com/mvs/ca/en/courses) to allow for deliberate practice, progressive operative responsibility, and remote coaching by experienced surgeons.

On the horizon, wearable technology has a role in surgical practice and education. GoPro (GoPro Inc, San Mateo, Calif) has been used as a tool to capture high-quality video for operative review and feedback. ${ }^{28}$ Google Glass (Google, Mountain View, Calif) has been 
used for teleproctoring surgeons across the world ${ }^{29}$ and live broadcasting of surgical procedures from the surgeon's view for the education of trainees. ${ }^{30}$

It is the hope that as technological options for learning expand, the most effective learning modalities can be individualized for trainees to maximize learning within the constraints of time.

\section{Teaching Technical and Nontechnical Skills}

Millennials prefer to learn both hard and soft skills on the job in collaborative and networked environments rather than through didactic lectures (Table 2). ${ }^{12}$ They excel at providing content-based answers, but synthesis, application, analysis, reasoning, and interpretation can be a challenge. ${ }^{31}$ Educators can help facilitate the learning of Millennials by emphasizing the relevance of what is being taught and how it can be applied. This can be accomplished through the "Flipped Classroom" model where technology is used to deliver the exponential growth in content knowledge external to time spent teaching by faculty. Faculty can focus their one-on-one teaching on the higher-level application of knowledge and critical thinking. ${ }^{32}$

As mentioned, Millennials also face significant external educational challenges in the current learning environment. For instance, teaching within the context of resident work-hour restrictions results in a reduction in resident surgical exposure. The use of specific goals or "milestones" can help to ensure consistency in that trainees are exposed to a similar breadth of surgical cases and that they accomplish mastery in a minimum set of surgical skills at each stage of their training. Furthermore, Millennials may be more adept with interdisciplinary or collaborative learning from pharmacists, nurse practitioners, perfusionists, physician assistants, anesthesia, cardiologist, and others. As always, there is a role for peer-to-peer teaching from senior to junior trainees. In the Canadian Competence-by-Design program, the final year of training is a transition-to-practice year designed to allow residents to independently manage a subset of patients in whom they operate on. ${ }^{33}$ Although not a new concept altogether, this is the first time that this has been formalized in Canada. Increased scrutiny and public reporting of surgical outcomes may discourage educators from training residents. We need to continue to incentivize teaching. In terms of outcomes, despite longer operative times, in carefully selected patients, having residents as the main operator in cardiac surgery does not appear to result in increased mortality or complications. ${ }^{1,34}$

The aforementioned Competence-by-Design education system in Canada $^{3}$ and the Accreditation Council for Graduate Medical Education Thoracic Surgery Next Accreditation System $^{35}$ have created guidelines for graduated goals based on a competency-based approach.
These educational paradigms may be key to the success in training Millennials in our specialty by creating transparency in what needs to be accomplished and its evaluation thereof, as well as a learner-centered rather than time-based model of training. Furthermore, simulation modules developed by the previous Joint Council for Thoracic Surgical Education are aimed to address technical and nontechnical skills, with accompanying assessment tools specific for training programs (http://learnctsurgery. sts.org/). ${ }^{36}$ Other modalities to develop nonoperative technical skills for cardiothoracic surgical trainees include clinical exposure and observation of role models as well as formally through workshops at international conferences and the LearnCTSurgery national curriculum developed by the Joint Council for Thoracic Surgical Education and operated by the Society of Thoracic Surgeons.

We should continually evaluate and refine our teaching strategies and educational paradigms to ensure that they meet our specialty's needs as well as the needs of our current learners. The establishment of the Thoracic Education Cooperative Group represents an important step toward this goal, because this group aims to conduct collaborative multi-institutional educational research to advance education and improve training in cardiothoracic surgery.

\section{Supervision and Feedback}

In contrast to Baby Boomers who tend to believe that "no news is good news," Millennials thrive on real-time objective performance data and interpret silence as negative feedback (Table 2). ${ }^{37}$ Educators should focus on learner-specific goals and develop benchmarks and milestones to measure progress and then provide regular feedback. Having said this, environments where grading may seem judgmental or subjective are more challenging for Millennials to accept. ${ }^{31}$ As such, every effort should be made to have transparent objective assessments and to deliver formative, frequent, specific, and actionable feedback. ${ }^{38}$ This approach allows Millennial learners the opportunity to make changes and effectively incorporate formative feedback to improve future performance. ${ }^{38}$ Faculty training on how to properly deliver appropriate feedback has always been necessary but will be vital for Millennial learners.

\section{Effective Team Dynamics and Training Environments}

Millennials tend to value leaders who listen well (Table 3). ${ }^{12}$ Millennials see leadership as part of a participative process - they expect to be partners with their leaders. They dislike micromanagement, but do want strong leadership with clear instructions, ${ }^{39}$ from leaders who are dependable, dedicated, and comfortable challenging the status quo. ${ }^{13}$ 
Teachers should be accessible, in person or digitally, and should engage students on a personal level. Focus on creating effective team dynamics in surgery and encouraging open communication can allow for more efficient teamwork and provide an opportunity for all perspectives to be shared and learned from. ${ }^{13}$ In working with interdisciplinary teams, which is an evolving reality in cardiothoracic surgery, surgeon teachers should demonstrate ways to navigate challenging decision making and conflicts within teams. This can also be accomplished through the use of simulation sessions focused on nonoperative technical skills, evidence-based guidelines, patient-centered care, being transparent with one's decisions and the underlying reasons, as well as thoughtfully eliciting and engaging the perspectives of other team members to tactfully come to a final decision.

In peer-to-peer training environments, wherever possible, the most senior trainee in the program should be delegated as the chief resident to oversee the schedules, teaching, and administrative tasks of junior learners. This will facilitate not only peer-to-peer education and mentorship, but also develop leadership skills that is integrated within their training curricula.

\section{HOW TO ATTRACT MILLENNIALS TO CARDIOTHORACIC SURGERY? Offer Value}

Offering value to trainees should be our specialty's foremost priority to ensure that we continue to attract and retain the best and brightest to cardiothoracic surgery. To get maximum productivity, loyalty, and admiration from people is to train, develop, encourage, support, and praise them. The lack of appreciation is often cited as a major factor for job dissatisfaction. ${ }^{40}$ Therefore, time to acknowledge a job well done and recognize that all team members bring value is important and may be especially important for Millennials.

Millennials have cited leadership, problem-solving, and skills training as their top 3 areas to develop. ${ }^{12}$ As such, it is incumbent upon programs to provide Millennials with protected time and dedicated resources to develop these areas through professional courses, coaching, and mentorship.

\section{Mentorship and Sponsorship}

Mentorship continues to be important for personal development, career selection, career satisfaction, advancement, success, and productivity. ${ }^{41}$ Programs should offer formal mentorship programs. In addition, residents should take advantage of networking, mentorship, fellowship, and award opportunities through our Societies, including the American Association for Thoracic Surgery, Society of Thoracic Surgeons, Women in Thoracic Surgery, Thoracic Surgery Foundation, and Thoracic Surgery Residents Association.
Social media is also a valuable tool to enhance the networking and mentorship for cardiothoracic surgeons to expand their professional networks, validate positive social identities, obtain social support, and find community. This can be especially the case for Millennials, who desire more diverse mentorship-even from individuals they have not met face-to-face (ie, social media). ${ }^{41,42}$ Furthermore, social media has a role in providing communities as well as inspiring the best and brightest trainees to pursue a career in cardiothoracic surgery. ${ }^{41-43}$

\section{Diversity and Inclusion}

Increasing diversity in the healthcare workforce is essential for the adequate provision of culturally competent care to our nation's diverse society. ${ }^{43}$ Individuals from prior generations regarded diversity and inclusion as an admirable goal to strive for; however, Millennials may see it as something to be expected. The imperatives include becoming "physician centered" (in addition to being patient centered) as we propose, implement, and evaluate the effectiveness of systemic solutions. Such strategies may include increasing the flexibility and transparency of tracks for promotion based on merit (eg, part-time positions with prorated tenure clocks and recognition of education and digital scholarship), ensuring representation and equity, support for work/life integration (eg, on-site infant, toddler, and child care facilities, elder care), and respecting competence and initiative (eg, provide surgeons and trainees time and resources for self-development that is necessary for them to perform at their best). Strategies specific for training residents include awareness of unconscious bias in evaluation, ensuring equity in the delegation of autonomy, ${ }^{44,45}$ faculty education, introspection, and a conscious effort to ensure that trainees are treated and taught as they deserve are needed to facilitate diversity and inclusion of all our trainees.

\section{Support of Our Surgical Teachers}

Surgical educators act as facilitators, role models, information providers, resource developers, planner, and assessors who juggle their teaching duties with responsibilities of patient care, research, and continuing professional development. $^{46}$ As always, we must incentivize operative teaching, embrace surgeons' educational efforts, and support the mission of educators through creation of nontraditional pathways for tenure and academic promotion. Furthermore, time and financial support should be offered to surgical educators to participate in educational professional development and training courses, such as the American College of Surgeons as Educators course. Other methods to support our surgical teachers include awards in education based on student evaluation, technical and examination performance, and sharing best practices, peer-reviewed curriculum, and 
resources between programs, which can be done through the Thoracic Education Cooperative Group or the American Association of Medical College MedEdPORTAL - the Journal of Teaching and Learning Resources. Rigorous evaluation of educational programs and their outcomes is needed and can be promoted by encouraging education as an academic career path.

\section{LOOKING TO THE FUTURE}

The insights gained as we develop strategies to better understand and train Millenials will reap rewards as we develop strategies for the next group of trainees, born after 1995, known as Generation Z. Data are lacking on Generation $\mathrm{Z}$ at this time; however, there will be a continued need for integratation of new technologies to facilitate teaching and learning (Tables 1-3). Ultimately, all generations share one overarching value, that of delivering the best care possible for the patients we serve. However, each generation differs in how they learn the skills necessary to do that, how they deliver that care, and how they embed that goal with other aspects of their life. For clarity, we do not suggest that the practicing surgeons of today should compromise their beliefs or priorities to please their trainees. We are proposing, however, that we are all actually more alike than we are different, and that there may be specific strategies that may be helpful to educators as they seek to transfer knowledge and skills to a different generation of learners.

\section{CONCLUSIONS}

Generational diversity brings differences in values and expectations, and it may affect teaching and learning styles, communication preferences, and expectations. Although we have offered some suggestions on how to address some of the gaps we identified, we have not provided an exhaustive list. Our goal is to start a discussion about the impact of generational differences on surgical education and to suggest strategies to optimize teaching for our learners. For Millennials, we suggest focusing on use of technology, teaching skills with context, providing regular and actionable feedback, and creating effective and safe learning environments. Awareness of the motivations and behaviors of Millennials can help to bridge the proverbial generational gap for cardiothoracic surgeon mentors to help them become more effective educators of the surgeons of tomorrow.

\section{Conflict of Interest Statement}

The authors reported no conflicts of interest.

The Journal policy requires editors and reviewers to disclose conflicts of interest and to decline handling or reviewing manuscripts for which they may have a conflict of interest. The editors and reviewers of this article have no conflicts of interest.

\section{References}

1. Tolis G, Spencer PJ, Bloom JP, Melnitchouk S, D'Alessandro DA, Villavicencio MA, et al. Teaching operative cardiac surgery in the era of increasing patient complexity: can it still be done? J Thorac Cardiovasc Surg. 2018;155:2058-65.

2. Tolis G. Cardiac surgical operative training: a disincentivized necessity. Eur J Cardiothorac Surg. 2019;55:173-7.

3. Antonoff MB, Luc JGY, Patterson GA, Meyers BF, Damiano RJ, Moon MR Graduate subspecialty and perceptions of cardiothoracic surgery training: a 60-year retrospective study. Ann Thorac Surg. 2019;107:285-93.

4. Ferdinand F, MacDonald J, Balkhy H, Bisleri G, Hwang HY, Northrup P, et al. Endoscopic conduit harvest in coronary artery bypass grafting surgery: an ISMICS systematic review and consensus conference statements. Innovations (Phila). 2017;12:301-19.

5. Kim AW, Reddy RM, Higgins RSD, Joint council for thoracic surgical education subcommittee best and brightest. "Back to the future";: recruiting the best and brightest into cardiothoracic surgery. J Thorac Cardiovasc Surg. 2010;140:503-4.

6. Luc JGY, Corsini EM, Mitchell KG. Effect of operating room personnel generation on perceptions and responses to surgeon behavior. Presented at: Academic Surgical Congress Annual Meeting; February 5-7, 2019; Houston, TX

7. Tolbize A. Generational differences in the workplace, 2008. Available at: https://rtc.umn.edu/docs/2_18_Gen_diff_workplace.pdf. Accessed July 1, 2019.

8. Beaman K. Generational change: change management for the ages. Workforce Solutions Review. August/September 2012:41-3.

9. Larson DL. Bridging the generation $X$ gap in plastic surgery training: part 1 . Identifying the problem. Plast Reconstr Surg. 2003;112:1656-61.

10. Larson DL. Bridging the generation X gap in plastic surgery training: part 2. A proposed solution-identifying a "best practice" in a plastic surgery training program. Plast Reconstr Surg. 2003;112:1662-5.

11. Stevens RJG, Hamilton NM. Is there a digital generation gap for E-Learning in plastic surgery? J Surg Educ. 2012;69:344-9.

12. Deal J. Retiring the Generation Gap: How Employees Young and Old Can Find Common Ground. San Francisco: Jossey-Bass Publishers; 2007.

13. Williams V, Medina J, Medina A, Clifton S. Bridging the millennial generation expectation gap: perspectives and strategies for physician and interprofessional faculty. Am J Med Sci. 2017;353:109-15.

14. Wittich C, Agrawal A, Cook D, Halvorsen AJ, Mandrekar JN, Chaudhry S, et al. E-learning in graduate medical education: survey of residency program directors. BMC Med Educ. 2017; 17:114.

15. Luc JGY, Verrier ED, Allen MS, Aloia L, Baker C, Fann JI, et al. Does cramming work? Impact of national web-based thoracic surgery curriculum login frequency on thoracic surgery in-training exam performance. J Thorac Cardiovasc Surg. 2018;156:922-7.

16. Loor G, Doud A, Nguyen TC, Antonoff MB, Morancy JD, Robich MP, et al. Development and evaluation of a three-dimensional multistation cardiovascular simulator. Ann Thorac Surg. 2016;102:62-8.

17. Barteit S, Jahn A, Banda S, Barnighausen T, Bowa A, Chileshe G, et al. E-Learning for medical education in Sub-Saharan Africa and low-resource settings: viewpoint. J Med Internet Res. 2019;21:e12449.

18. Antonoff MB, Verrier ED, Allen MS, Aloia L, Baker C, Fann JI, et al. Impact of Moodle-based online curriculum on thoracic surgery in-training examination scores. Ann Thorac Surg. 2016;102:1381-6.

19. Lourenco AP, Cronan JJ. Teaching and working with Millennial trainees: impact on radiological education and work performance. J Am Coll Radiol. 2017;14:92-5.

20. Luc JGY, Varghese TK, Antonoff MB. Participating in a TweetChat: practical tips from the thoracic surgery social media network (\#TSSMN). Ann Thorac Surg. 2019;107:e229-33.

21. Luc JGY, Antonoff MB. Live Tweet the Society of Thoracic Surgeons annual meeting: how to leverage twitter to maximize your conference experience. Ann Thorac Surg. 2018;106:1597-601.

22. Ni hlci T, Archer M, Harrington C, Luc JGY, Antonoff MB. The trainee thoracic surgery social media network: a pilot study in social media use. Ann Thorac Surg. 2020;109:285-90.

23. Luc JGY, Archer MA, Arora RC, Bender EM, Blitz A, Cooke DT, et al. Social media improves cardiothoracic surgery literature dissemination: results of a randomized trial. Ann Thorac Surg. 2020;109:589-95.

24. Luc JGY, Ouzounian M, Bender EM, Blitz A, Stamp NL, Varghese TK, et al. The thoracic surgery social media network: early experience and lessons learned. J Thorac Cardiovasc Surg. 2019;158:1127-36. 
25. Luc JGY, Ouzounian M, Bender EM, Blitz A, Stamp NL, Varghese TK, et al. The thoracic surgery social media network: early experience and lessons learned. Ann Thorac Surg. 2019;108:1248-55.

26. Antonoff MB. Using social media effectively in a surgical practice. J Thorac Cardiovasc Surg. 2016;151:322-6.

27. Cardall S, Krupat E, Ulrich M. Live lecture versus video-recorded lecture: are students voting with their feet? Acad Med. 2008;83:1174-8.

28. Moore M, Abelson J, O'Mahoney P, Bagautdinov I, Yeo H, Watkins A. Using GoPro to give video-assisted operative feedback for surgery residents: a feasibility and utility assessment. J Surg Educ. 2018;75:497-502.

29. Datta N, MacQueen IT, Schroeder AD, Wilson JJ, Espinoza JC, Wagner JP, et al. Wearable technology for global surgical teleproctoring. J Surg Educ. 2015;72: 1290-5.

30. Lee N. Surgical training through the looking glass. Lancet Technol. 2014;384:573.

31. Roberts D, Newman L, Schwartzstein R. Twelve tips for facilitating Millennials' learning. Med Teach. 2012;34:274-8.

32. Kraut A, Omron R, Caretta-Weyer H, Jordan J, Manthey D, Wolf SJ, et al. The flipped classroom: a critical appraisal. West J Emerg Med. 2019;20: 527-36.

33. Noly PE, Rubens FD, Ouzounian M, Quantz M, Wang SH, Pelletier M, et al. Cardiac surgery training in Canada: current state and future perspectives. $J$ Thorac Cardiovasc Surg. 2017;154:998-1005.

34. Bloom J, Heng E, Auchincloss H, Melnitchouk SI, D’Alessando DA, Villavicencio MA, et al. Cardiac surgery trainees as "skin-to-skin" operating surgeons: midterm outcomes. Ann Thorac Surg. 2019;108:262-7.

35. Joint Council on Thoracic Surgery Education. Thoracic surgery milestones resource manual. 2014. Available at: https://www.tsda.org/wp-content/uploads/ 2014/11/JCTSE-TS-Milestones-Resource-Manual-FINAL-2.pdf. Accessed July $1,2019$.

36. Trehan K, Kemp CD, Yang SC. Simulation in cardiothoracic surgical training: where do we stand? J Thorac Cardiovasc Surg. 2014;147:18-24.e2.
37. Cahill T, Sedrak M. Leading a multigenerational workforce: strategies for attracting and retaining millennials. Front Heal Serv Manag. 2012;29:3-15.

38. Chen P, Scanlon M. Teaching radiology trainees from the perspective of a Millennial. Acad Radiol. 2018;25:794-800.

39. Joyner T. Gen X-ers focus on life outside the job fulfillment. The Secured Lender May/Jun; 2000. Available at: http://findarticles.com/p/articles/mi_qa5352/is_ 200005/ai_n21455443. Accessed July 1, 2019.

40. Johnson M. Go ahead and fire me!: the top three things generation Y does not like about working@your medical practice. J Med Pr Manag. 2014;30:60-3.

41. Luc JGY, Stamp NL, Antonoff MB. Social media in the mentorship and networking of physicians: important role for women in surgical specialties. Am J Surg. 2018;215:752-60.

42. Luc JGY, Stamp NL, Antonoff MB. Social media as a means of networking and mentorship: role for women in cardiothoracic surgery. Semin Thorac Cardiovasc Surg. 2018;30:487-95.

43. Stamp NL, Luc JGY, Ouzounian M, Bhatti F, Ni Hici T, Antonoff MB. Social media as a tool to rewrite the narrative for women in cardiothoracic surgery Interact Cardiovasc Thorac Surg. 2019;28:831-7.

44. Meyerson SL, Teitelbaum EN, George BC, Schuller MC, DaRosa DA, Fryer JP. Defining the autonomy gap: when expectations do not meet reality in the operating room. J Surg Educ. 2014;71:e64-72.

45. Meyerson SL, Sternbach JM, Zwischenberger JB, Bender EM. Residen autonomy in the operating room: expectations versus reality. Ann Thorac Surg. 2017; 104:1062-8.

46. Khan N, Khan MS, Dasgupta P, Ahmed K. The surgeon as educator: fundamentals of faculty training in surgical specialties. BJU Int. 2012;111: 171-8.

Key Words: generation, millennial, surgical education 